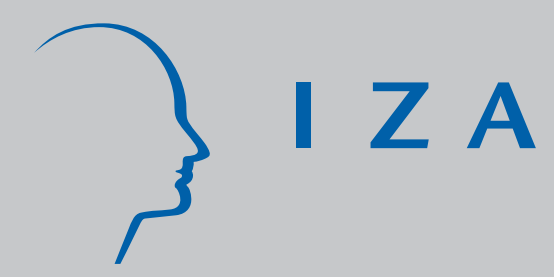

IZA DP No. 1725

Religious Affiliation and Participation as Determinants of Women's Educational Attainment and Wages

Evelyn Lehrer

August 2005 


\title{
Religious Affiliation and Participation as Determinants of Women's Educational Attainment and Wages
}

\author{
Evelyn Lehrer \\ University of Illinois at Chicago \\ and IZA Bonn \\ Discussion Paper No. 1725 \\ August 2005
}

IZA

P.O. Box 7240

53072 Bonn

Germany

Phone: +49-228-3894-0

Fax: +49-228-3894-180

Email: iza@iza.org

\begin{abstract}
Any opinions expressed here are those of the author(s) and not those of the institute. Research disseminated by IZA may include views on policy, but the institute itself takes no institutional policy positions.

The Institute for the Study of Labor (IZA) in Bonn is a local and virtual international research center and a place of communication between science, politics and business. IZA is an independent nonprofit company supported by Deutsche Post World Net. The center is associated with the University of Bonn and offers a stimulating research environment through its research networks, research support, and visitors and doctoral programs. IZA engages in (i) original and internationally competitive research in all fields of labor economics, (ii) development of policy concepts, and (iii) dissemination of research results and concepts to the interested public.
\end{abstract}

IZA Discussion Papers often represent preliminary work and are circulated to encourage discussion. Citation of such a paper should account for its provisional character. A revised version may be available directly from the author. 


\title{
ABSTRACT
}

\section{Religious Affiliation and Participation as Determinants of Women's Educational Attainment and Wages*}

\begin{abstract}
Using a human capital model, this paper develops hypotheses about how religious affiliation and participation during childhood influence years of schooling completed and subsequent performance in the labor market as measured by wages. The hypotheses are tested using data from the 1995 National Survey of Family Growth, a large-scale survey addressed to a representative sample of women in the United States. Religious affiliation is found to have a significant impact on years of schooling completed, with the effects being particularly pronounced for Jews and conservative Protestants. The impact of religious affiliation on wages largely mirrors its influence on educational attainment, although evidence of additional effects operating through other channels is also uncovered. In addition, the results show that youth who attend religious services frequently during childhood go on to complete more years of schooling than their less observant counterparts.
\end{abstract}

JEL Classification: J24, J31

Keywords: religion, education, wages

Corresponding author:

Evelyn Lehrer

Economics Department (m/c 144)

University of Illinois at Chicago

601 S. Morgan Street

Chicago, IL 60607-7121

USA

Email: elehrer@uic.edu

\footnotetext{
* I have benefited from helpful comments on earlier drafts by Barry Chiswick, and by participants at the conference on "Religion, Health, and Families in the United States", University of Austin, Texas, April 23-24, 2004, and at the 2005 meetings of the Population Association of America, Philadelphia.
} 


\section{INTRODUCTION}

Recent years have witnessed a renewed interest on the relationship between religious affiliation and education. Analyses of data on non-Hispanic whites from the 1987-88 National Survey of Families and Households (NSFH) reveal that for both men and women, mainline Protestants and Catholics are at the center of the educational distribution; the mean years of schooling is about one year lower for conservative Protestants, and about two years higher for Jews (Lehrer 1999). Other research confirms that the level of schooling is relatively high for Jews (Chiswick 1983, 1988) and relatively low for conservative Protestants (Darnell and Sherkat 1997; Sherkat and Darnell 1999; Glass (1999). Other groups, including Mormons and the unaffiliated, have not been studied in most of these analyses.

There is also a growing interest in the question of how educational outcomes may be affected by another dimension of religion, namely, religiosity. Religiosity encompasses such dimensions as commitment to the religion, the strength of religious beliefs, and participation in religious activities individually or as part of a congregation. Studies that have examined the linkage between religiosity and education suggest a positive association. Freeman (1986) finds a positive effect of churchgoing on school attendance in a sample of inner-city black youth. Regnerus (2000) finds that participation in religious activities is related to better test scores and heightened educational expectations among tenth-grade public school students. Based on data on adolescents from the National Education Longitudinal Study of 1988, Muller and Ellison (2001) report positive effects of various measures of religious involvement on the students' locus of control (a measure of self concept), educational expectations, time spent on homework, advanced mathematics credits earned, and the probability of obtaining a high school diploma. 
The present study employs data from a large-scale national survey addressed to women, the 1995 National Survey of Family Growth (NSFG). Most of our knowledge with regard to the religious affiliation-education linkage is based on data collected in the 1980 s and before. This more recent data set provides an opportunity to ascertain whether the relationships found earlier for the main religious groups continue to hold. In addition, the sample size is big enough to allow inclusion of relatively small groups in the analysis, including Jews, Mormons, and the unaffiliated. Another attractive feature of this survey is that it contains a variable on one aspect of religiosity measured at an early age, namely, how frequently the respondent attended religious services when she was 14 years old. This information makes it possible to study how religious participation during the formative years is related to subsequent decisions regarding investments in schooling. This relationship has been examined for the case of conservative Protestants (Lehrer 2004b); the present study extends this analysis to the other main religious groups in the U.S.

The evidence accumulated thus far in the literature on how religious affiliation and participation affect education suggests that these religious variables should exert similar influences on measures of subsequent economic well-being as an adult. Indeed, Keister (2003) finds that patterns of wealth accumulation by religious affiliation closely mirror the differences by education described above: Jews are at the upper end of the distribution, with very high levels of wealth accumulation; conservative Protestants have relatively low levels, and mainline Protestants and Catholics are at the center of the distribution; the author also documents a positive impact of religious participation on wealth. Evidence on the effects of religious affiliation on other indicators of economic well-being, such as hourly wages or earnings, is very limited, with the notable exception of studies that find a large positive effect associated with a Jewish upbringing (Chiswick, B. 1992, 1993). Moreover, there have been no analyses to date of how religious participation may affect 
performance in the labor market. The present study seeks to close these gaps in our knowledge, for the case of women.

\section{ANALYTICAL FRAMEWORK The Effects of Religious Affiliation and Participation on Education}

Recent research has interpreted patterns of religious differentials by education within the context of the human capital model developed by Becker and Chiswick (1966) and Becker (1967). In this framework, religious affiliation is viewed as reflecting distinctive features of the home environment that can affect the supply and/or demand for funds for investments in schooling (Chiswick, B. 1988; Lehrer 1999). On the demand side, religious affiliation can affect the returns from investments in education: among religious groups characterized by larger benefits from schooling, the incentives to pursue education are stronger and thus a higher level of attainment is expected, ceteris paribus. On the supply side, religious affiliation can affect the parents' willingness and ability to supply funds for such investments: a higher level of education is expected for religious groups in which the parents have a greater willingness and ability to supply funds for investments in schooling, ceteris paribus. This framework is used below to organize various ideas suggested in earlier studies and to develop hypotheses regarding the effects of religious affiliation and participation on educational attainment. ${ }^{1}$ Mainline Protestants are used as the reference category for all comparisons.

Conservative Protestants. There are reasons to believe that the level of schooling is relatively low for this group, for both supply and demand reasons. On the supply side, conservative Protestant parents often have concerns that secular schooling may adversely affect their children and this influences their willingness to supply funds for investments in their schooling. As Darnell and 
Sherkat (1997, p. 308) note, a literal interpretation of the Bible leads to hostility towards the scientific method, because this approach to learning "seeks to discover truths rather than claiming to know 'The Truth.' Scientific discoveries are seen as promoting alternatives to divine truths already specified in scripture.” Conservative Protestants are also concerned about the challenge that a humanistic education may pose to their beliefs: "the humanistic values openly taught or implied in secular curricula are frequently in conflict with conservative Protestants' conceptions of authority and submission — particularly the authority of the Bible as the inerrant word of God, and the need for children to submit to the will of their parents” (Sherkat and Darnell 1999: p. 24). Parents’ reservations about the learning that takes place in secular institutions are particularly pronounced at the college level; at the same time, the opportunities to attend religious institutions of higher education are limited and expensive.

On the demand side, a fundamentalist upbringing may imply lower levels of certain types of home investments in child quality that increase the productivity of formal schooling, in part because it is associated with an authoritarian approach to knowledge and a rejection of critical inquiry and unconventional modes of thinking (Sherkat and Darnell 1999). In addition, as the authors observe (p. 26), "combining the antieducational schemata fostered in fundamentalist religious structures with their views on family life, it seems reasonable that parents will actively seek to hinder their children's interactions with secular educational resources.” During the high school years, fundamentalist orientations have an adverse effect on the probability that a student will take courses that provide valuable background for more advanced schooling: "these college preparatory courses are the ones fundamentalists find most harmful to their children, because of their advocacy of humanism, evolution, cultural tolerance, and variable based approaches to mathematics” (Darnell and Sherkat 1997: 7). Children raised in conservative Protestant homes may thus find that their access to high 
quality universities is more restricted.

Catholics. A large body of research shows that there has been a convergence between Catholics and mainline Protestants in recent decades, in most aspects of economic and demographic behavior (Jones and Westoff 1979; Brinkerhoff and MacKie 1988; Lehrer and Chiswick 1993; Lehrer 1996). Consistent with this transformation that has taken place, there is some evidence that non-Hispanic Catholics and mainline Protestants do not differ significantly in terms of educational attainment (Lehrer 1999). ${ }^{2}$ It is expected that this pattern will also be observed with the more recent data.

Jews. Chiswick, B. (1988) presents arguments suggesting that for Jews, educational attainment is high for both demand and supply reasons. On the demand side, family size tends to be small (Della Pergolla 1980) and a large amount of resources, especially maternal time, are invested in each child during the early, formative years (Chiswick, B. 1986). These investments increase the productivity of formal education and thus the benefits from additional investments in schooling are high. On the supply side, the “diaspora hypothesis” posits that historically, Jews have placed a high priority on making investments in the human capital of their children, as these are more portable than investments in physical capital (Brenner and Kiefer 1981). ${ }^{3}$ Parents would thus be willing to invest more in the human capital of their offspring at any given interest rate, also implying a higher level of educational attainment.

Mormons. As Albrecht and Heaton (1984) note, the Mormon Church has emphasized the importance of education from its very beginning. Theoretically, this high priority placed by the Mormon religion on schooling is a supply-side force that should lead to a high level of educational attainment. At the same time, however, the Mormon religion is characterized by a strongly pronatalist theology. The early entry into motherhood and extended length of the child-rearing period that are associated with 
high fertility imply a relatively low level of lifetime involvement in labor market activity for women, with correspondingly low expected market returns from schooling. Thus on the demand side, Mormon women should have fewer incentives than their mainline Protestant counterparts to make investments in secular education, and their schooling level is expected to be relatively low. There is little empirical evidence on this issue to date. Albrecht and Heaton (1984) find that for both men and women, the educational attainment of Mormons exceeds that of the U.S. population as a whole. In contrast, Keysar and Kosmin (1995), who analyze a sample of female respondents only, find that the probability of going on to higher education for Mormons is not significantly different from that of their reference category, the unaffiliated (a group that appears to have low attainment, as discussed below).

The Unaffiliated, and the Role of Religious Participation. Individuals who report that they were raised with "no religion" constitute a relatively small and heterogeneous group. ${ }^{4}$ In one of the few studies that include it, Glass (1999) finds that youths growing up with no religion have a lower level of schooling than those who have some religious affiliation.

Theoretically, the effect on education of growing up with no affiliation can best be understood following Glenn (1987), thinking of the "no religion" category as an extreme point in the religiosity scale: children who grew up unaffiliated had no involvement in religious activities during childhood, at least not in an institutional context. ${ }^{5}$

A growing body of literature shows that some religious involvement may be associated with benefits in a wide range of areas (Waite and Lehrer 2003; Smith 2003). In particular, religious participation among youths has been linked to a lower probability of substance abuse and juvenile delinquency (Donahue and Benson 1995); a lower incidence of depression among some groups 
(Harker 2001); delayed sexual debut (Bearman and Bruckner 2001) and entry into cohabitation (Lehrer 2004a); more positive attitudes toward marriage and having children; and more negative attitudes toward unmarried sex and premarital childbearing (Marchena and Waite 2001).

Several studies show that the positive outcomes associated with religious involvement also include better performance in the area that is the focus of this paper: education (Freeman 1986; Regnerus 2000; Muller and Ellison 2001). These studies have noted that by contributing to the development of social capital, religion can play a helpful role in the socialization of youth. Religious congregations often sponsor family activities, stimulating the cultivation of closer parent-child relations; they also bring children together with grandparents and other supportive adults (parents of peers, Sunday-school teachers) in an environment of trust. This broad base of social ties can be a rich source of positive role models, confidants, useful information, and reinforcement of values that promote educational achievement. In addition, most religions encourage healthy behaviors and discourage conduct that is self-destructive, and participation in religious activities can promote emotional well-being (Levin 1994; Regnerus 2003). In these and other ways (see Smith 2003), involvement in religious activities can lead to better mental health, more constructive behaviors, and greater access to valuable resources, all of which are conducive to better schooling outcomes.

The arguments presented above suggest that if one compares children who grow up with no religious affiliation to their counterparts with an affiliation, the latter should have a higher level of educational attainment for demand-side reasons: such children may have lower psychological costs of attending school, and their time spent on human capital investments is likely to be more productive.

In terms of the continuous religiosity variable, a higher level of religious involvement is expected to have a positive impact on educational attainment for the same reasons. However, the effects may well be different across religious groups. Although this issue has not been studied 
systematically, there is some evidence that religious participation is especially valuable for those who are more vulnerable, for reasons that might include poor health, challenging family circumstances, and adverse economic conditions (Hummer et al. 2002). Thus the favorable effects of religious involvement may be especially important for conservative Protestants, given the evidence to date that their level of economic well-being is relatively low. At the same time, however, there are other reasons to believe that religiosity could actually be a negative force within this group: the adverse effects on educational attainment associated with the conservative Protestant theology are likely to be more pronounced among those who are more observant.

\section{The Effects of Religious Affiliation and Participation on Wages}

Religious affiliation during childhood is expected to influence wages through its impact on years of schooling completed, discussed above, and also through its effects on employment and labor market experience (Lehrer 1995; Sherkat 2000). Additional effects may be expected. Relatively high levels of wealth accumulation among Jewish families are likely to be associated with attendance to schooling institutions of higher quality, which would also lead to higher wages. In addition, Keister (2003, p. 180) suggests that in their investments, Jews may benefit from a cultural repertoire transmitted across generations that encourages this-worldly pursuits. Furthermore, as she notes, “Social connections developed through schools and universities can provide information about investment strategies, actual investment opportunities, and access to capital for investing. Family contacts and contacts in the local Jewish community can also provide information, access to investments, and support that make investment feasible...” This social capital may also be of help in the labor market, and if so, affiliation with the Jewish faith would have a positive impact on wages 
even after controls for education and experience. The tendency for Jews to reside in large metropolitan areas where wages are high, like New York City, is another factor.

At the same time, Ellison and Bartkowski’s (2002) analysis implies a possible negative effect for the case of conservative Protestant women, beyond the channel operating through a lower level of schooling and labor market experience. The authors find that in conservative Protestant families, there is greater asymmetry in the intra-household division of labor, and the wives spend more time on household work. To the extent that heavier responsibilities for work in the home decrease the level of energy left for market work, the result may be lower productivity on the job and lower wages. ${ }^{6}$ For these effects that operate through mechanisms other than education and experience, religious affiliation as an adult should be more relevant than affiliation during childhood.

As to religiosity, involvement in religious activities during childhood is expected to influence wages through its impact on educational attainment. During the adult years, religious participation may reinforce some of the other effects on wages identified above.

\section{DATA AND METHODS}

The empirical analysis uses data from Cycle 5 of the National Survey of Family Growth. The survey was conducted in 1995 by the Research Triangle Institute, under contract from the National Center for Health Statistics (see Kelly et al. 1997 for a description of the methodology). The questionnaires were addressed to a nationally representative sample of 10,847 civilian, noninstitutionalized women ages 15-44 of all marital statuses living in the United States. The interviews included questions on socioeconomic and family background variables, as well as information on religion, educational attainment, marriage, employment, and fertility. 
The sample is restricted in three ways. First, patterns of investments in human capital differ markedly by race and ethnicity and thus only non-Hispanic white respondents born in the United States are included in the analysis. ${ }^{7}$ Second, the sample is limited to women who were born before 1969 (ages 27 and older in 1995). Respondents with later birth dates are excluded because at the time of the survey they were in age categories where the schooling process is often not yet complete. Third, the sample is restricted to individuals who were raised in one of the following faiths: Roman Catholic, mainline Protestant (Presbyterian, Episcopalian, Methodist, Lutheran, Protestant with no specific denominational affiliation), conservative Protestant (Baptists and various smaller denominations associated with Pentecostal, charismatic, evangelical, and fundamentalist movements, including Assembly of God, Church of Christ, and Holiness), ${ }^{8}$ Jewish, Mormon, and no religion. After deleting also cases with missing information for the key variables, the resulting sample size is 4,181 .

The religiosity variable is based on information in the 1995 NSFG on the respondents' frequency of attendance to religious services at age 14. This is a measure, albeit an imperfect one, of the young women's involvement with religion at that age. Unfortunately, the survey does not contain information on other dimensions of religiosity at that time, nor does it contain any questions on the parents' religiosity. The working assumption used here is that at age 14, the child's behavior in the religious arena closely mirrors that of her parents. ${ }^{9}$ Religious participation is operationalized as a dichotomous variable. Individuals who attended religious services 1-3 times per month or more frequently are classified in the high religiosity category; others are placed in the low religiosity group. The 1995 NSFG also includes information on religious affiliation at the time of the interview, and on frequency of attendance to religious services five years prior to the survey. These variables are used as measures of adult affiliation and participation in the wage analyses. ${ }^{10}$ 
Table 1 presents definitions and means for the two childhood religion variables described above: the affiliation in which the respondent was raised and her religious participation at age 14 . The adult religion variables are defined in the same way. The variables used as controls in the regressions are defined in Table 2. The education models include the parents' average years of

schooling, ${ }^{11}$ dummy variables for family structure at age 16 , whether the mother was 18 years of age or younger at the time of her first birth, the size of the family of origin, and region of residence at birth. It would have been desirable to also control for the rural-urban nature of the area where the respondent grew up; unfortunately this information is not available. The controls for the wage regressions are the years of schooling completed by the respondent, years of full-time and of parttime work experience, and region of residence and rural/ urban location at the time of the survey.

\section{EMPIRICAL RESULTS}

\section{Effects on Educational Attainment}

Table 3 reports regressions with years of regular schooling completed as the dependent variable. Consistent with results based on data from the 1980s (Lehrer 1999), the zero-order regression reveals that mainline Protestants and Catholics are at the center of the distribution; Jews have a higher level of education, by a margin of about 2.3 years, and conservative Protestants have a lower level, by a margin of about 1.2 years. The results also show that Mormons and the unaffiliated complete about six-tenths of a year less than the reference group.

All of the religion coefficients decrease in size when controls for family background variables (excluding parental education) are added in the next column, with the exception of the Catholic coefficient. Examination of means for the background variables separately by religious affiliation reveals that this is due to the fact that Catholic respondents had a larger family size than mainline 
Protestants, consistent with the high fertility pattern that used to characterize the Catholic population (Jones and Westoff 1979). The Catholic coefficient in this second column, though significant, is small in size, showing relatively little difference between mainline Protestants and Catholics.

A control for parental education is added in the last column. Two effects remain sizeable in this specification. Ceteris paribus, conservative Protestants attain half a year less of schooling than mainline Protestants, and Jews complete about a year and a half more. A modest negative gap of a third of a year is observed for Mormons, along with a small positive gap for Catholics; the coefficient on the no religion variable is negative but not significant at conventional levels.

The "true" effect of religious affiliation on education, net of other factors, can be thought of as being bracketed by the estimates in columns two and three. Parental education is the best proxy for socioeconomic status in these data, and the positive coefficient on this variable in part captures an income effect that should be controlled for. At the same time, however, the education differentials by religion in the respondents' generation are mirrored by corresponding differences in their parents' generation, which are due in part to the influence of religion.

Turning to the coefficients on the other background variables, a nonintact family, a larger number of siblings, and having a mother who entered parenthood early all affect schooling negatively. The geographical area variables do not attain significance. The coefficients on these control factors provide a way to assess the relative importance of religious affiliation. For example, compared to the reference category, the coefficient on the Mormon variable in the last specification implies an influence on years of schooling completed similar in magnitude to that of having lost a parent; the coefficient on the conservative Protestant variable is similar to that of having a mother who entered parenthood at age 18 or before. 
Table 4 examines the effects of religious participation on educational attainment for the case of mainline Protestants, conservative Protestants, and Catholics. Sample size limitations precluded the possibility of examining these relationships also for Jews and Mormons.

The zero-order effects shown in the first column reveal a significantly positive influence associated with religious involvement for each of the three groups studied. The difference in years of schooling completed between the high and low religiosity group is one year for conservative Protestants and the same is true for Catholics. The difference is smaller for mainline Protestants: about four tenths of a year. All of these differences remain significant in the next two models. The mainline Protestant effect falls to three-tenths of a year; the influences for Catholics and conservative Protestants both remain sizeable: between seven- and nine-tenths of a year. These results lend support to the hypothesis that children who grow up in homes where there is more religious involvement do better in terms of educational attainment. Empirically, the margin is found to be substantial in the case of Catholics and conservative Protestants, and modest in the case of mainline Protestants.

These estimates must be qualified as possibly subject to some biases. If church attendance is correlated with unobserved factors that encourage good behaviors in general, the present results would overstate the positive causal effect of religiosity on educational attainment. This would be the case, for example, if the more observant parents, who encourage their children to attend religious services, are also supportive of activities that are conducive to success in the secular arena. In interpreting his finding that among black youths, churchgoing is positively associated with school attendance, Freeman (1986) has emphasized this type of bias: he cautions that the true causal impact of religious participation on educational outcomes may in fact be smaller than suggested by his estimates. 
An argument can also be made, however, for biases operating in the opposite direction. As noted earlier, there is some evidence that religious participation may be especially valuable for individuals who are more vulnerable (Hummer et al. 2002). To the extent that such individuals are aware of this and respond by embracing religiosity as a coping mechanism, the more religious homes would disproportionately have unobserved characteristics that affect educational outcomes adversely. If so, the estimated coefficients would understate the true impact of religiosity on educational attainment. A priori, it is unclear which biases are dominant.

\section{Effects on Wages}

Table 5 presents regressions with the log of the wage rate as the dependent variable. ${ }^{12}$ These

results are based on the sub-sample of respondents who were employed as of the survey date. ${ }^{13}$ Two measures of religion are used: the affiliation in which the respondent was raised, and her affiliation at the time of the interview.

Focusing first on the zero-order regressions, the results show that mainline Protestants are at the center of the wage distribution in both specifications, with the childhood and adult religion measures. A Catholic advantage of $7 \%$ can be observed with the childhood religion measure, but the effect is insignificant with the adult religion measure. ${ }^{14}$ The opposite holds for the no-religion variable: the model with current affiliation suggests a disadvantage of about $11 \%$, but the effect is insignificant in the model with childhood religion. Both specifications show a wage disadvantage for conservative Protestants and Mormons- of about 17-23 \% and 26-35\%, respectively- and a large advantage of 79-81 \% for Jewish women.

The specifications that include other determinants of wages provide estimates of the influence that remains after controlling for years of schooling, experience, and place of residence. The Catholic 
effect is insignificant with both religion measures. Being unaffiliated is associated with an adverse impact of about $7 \%$ in the specification based on adult affiliation; the effect is insignificant in the specification based on childhood affiliation. The Jewish effect falls from $79-81 \%$ in the zero-order regressions to about $39-40 \%$ in the regressions with controls, implying that approximately one half of the wage advantage of Jewish women is due to their higher level of educational attainment and related labor market characteristics; the other half reflects the effects of other factors not measured in these data, such as helpful social capital in the labor market, higher quality of schooling, and residence in high-wage metropolitan areas. The Mormon effect also falls, from 26-35\% to 21-28\%. In this case, a relatively small fraction of the effect is due to the influence through educational attainment and experience in the labor market. Future analyses might extend the work by Ellison and Bartkowski (2002) and explore the possibility that Mormon families, like their conservative Protestant counterparts, are characterized by greater asymmetry in the intra-household division of labor than mainline Protestant families.

An interesting difference between the results for childhood and adult religion emerges for the case of conservative Protestants: while the effect is insignificant in the specification based on childhood religion, a significant difference of about $7 \%$ is observed in the model that uses adult affiliation. This pattern is consistent with the fact that adult religion is most relevant for the negative influence stemming from conservative Protestant women’s greater involvement in household tasks. ${ }^{15}$

Overall, the results suggest that religious affiliation is an important determinant of wages, with some of the effects being strikingly large. Additional research will be needed to confirm these results, with data sets that contain more precise wage information along with more detailed information on other determinants of wages such as place of residence. 
In marked contrast, the regressions reported in Table 6 show that religious participation is generally not an important determinant of wages for the three groups considered: conservative Protestants, mainline Protestants, and Catholics. The earlier analyses showed that for mainline Protestants, the effect of religious participation on educational attainment is only modest in size; it is thus not surprising that there is no discernible effect on performance in the labor market later in life, as measured by wages. The impact of religious participation on the educational attainment of Catholics was found to be sizeable, and a significant effect is observed on wages in the model of column 1: Catholics who attended services frequently during adolescence have a wage advantage compared to their coreligionists who grew up with less religious observance; however, this influence disappears when education and other background variables are held constant. The two models that use adult religion show no significant Catholic effect.

With regard to conservative Protestants, there are opposing forces. On the one hand, religious participation during childhood was shown above to have a positive influence on years of schooling; it may also have a beneficial effect on other dimensions of educational attainment that were not measured here, such as academic performance. On the other hand, conservative Protestants display more traditional behaviors regarding the division of labor within the home, and the negative repercussions for female wages are expected to be stronger among those who are more observant. These countervailing forces, along with the positive correlations between childhood and adult religious affiliation and participation, probably account for the observed zero net effect of participation on wages for conservative Protestants in all specifications. 


\section{CONCLUSIONS AND DIRECTIONS FOR FUTURE RESEARCH}

This paper examined the role of religious affiliation and participation on the educational attainment and wages of women in the United States, using data on respondents ages 27-44 from the 1995 National Survey of Family Growth. The empirical results confirm earlier findings suggesting that ceteris paribus, mainline Protestants and Catholics are at the center of the educational distribution, conservative Protestants attain less schooling, and Jews attain more. In addition, the results suggest that being raised as a Mormon or with no religious affiliation have negative influences on schooling. A human capital model helps interpret these findings as resulting from demand and supply side forces associated with membership in various religious groups.

Religious participation during childhood is hypothesized to have a positive impact on educational attainment due to demand-side effects: the beneficial impact of religious involvement on children's ability to be productively engaged in schooling endeavors. Results for the case of Catholics, conservative Protestants, and mainline Protestants, lend support to this hypothesis and indicate that the positive influences are especially pronounced for the first two groups.

The effects of religious affiliation on wages largely mirror its influences on educational attainment. However, the results suggest that religious affiliation also exerts additional effects, beyond its impact through differences in years of schooling and related differences in labor market experience. The very high wages of Jews may in part reflect a higher level of schooling quality, social capital that is helpful in the labor market, and a tendency to reside in large metropolitan areas. In the case of conservative Protestants, their relatively low wages may be due in part to asymmetry in the intra-household division of labor, and a similar explanation may account for the low wages of 
Mormon women. While the results of this study suggest that affiliation is an important determinant of wages, within-group variation in religious participation was found to have little or no effect.

The present analysis raises new questions for future research. Additional investigation is needed to explore possible explanations for the finding that the beneficial effects of religious participation are higher for Catholic and conservative Protestant youth than for their mainline Protestant counterparts. Smith (2003) notes that the quality and quantity of constructive influences provided to youth vary across religious organizations, and research along these lines may provide some answers. Other research suggests it would also be useful to explore the role of theological conservatism (Ellison et al. 1996; Wilcox 1998), which is unfortunately not measured in the 1995 NSFG. In addition, it would be desirable to replicate these analyses using data sets with much richer information on the home environment, so that problems of selectivity bias may be addressed and more accurate estimates of the causal effect of religious participation on educational attainment can be produced. Whether the effects for men are similar to those found here for women, and whether the results hold also for other racial and ethnic groups, are yet other questions worth pursuing in future work.

Finally, the present analyses specified religious participation as a dichotomous variable, indicating high or low frequency of attendance to religious services. Future research with larger sample sizes might refine this specification, as the effects of religiosity may be non-linear: higher levels of involvement in religious activities during childhood may have beneficial effects, but only up to a point. Beyond a certain level, participation in religious activities might crowd out investments in secular human capital. Furthermore, there may be important differences between those who never attended religious services during adolescence versus those who did so infrequently. Our 
understanding of the complex effects of religious affiliation and participation on education and wages will improve as future research begins to provide answers to these various questions. 


\section{ENDNOTES}

Another attractive feature of this theoretical framework is that it yields predictions regarding religious differentials in the rate of return from schooling investments, thus making it possible to ascertain in each case whether demand or supply side forces are dominant (Chiswick 1988; Lehrer 1999). This aspect of the model is not pursued in the present paper because the rate-of-return calculations require separate analyses for various religious affiliation/ religiosity groups and many of the sub-samples in the 1995 NSFG are too small for this purpose.

2 See Sander (1995) for a discussion of related research on the effects of Catholic schools on educational attainment.

$3 \quad$ See Ayal and Chiswick (1983) for additional discussion of this hypothesis. The authors emphasize that only some investments in human capital are highly transferable, being equally productive in all locations. Others (such as an education in law) are not portable.

$4 \quad$ An analysis of 110 U.S. national surveys reveals an increase in the number of "no religion” responses from the late 1950s to the early 1980s, with some sign of leveling off or reversal afterwards (Glenn 1987).

5 It is possible to believe in the supernatural and have personal religious and spiritual experiences outside of the institutional context; see Stark and Bainbridge (1985).

$6 \quad$ Becker (1985) has argued that women with heavier child care and household responsibilities may seek jobs that are more convenient, require less energy, and pay lower wages.

$7 \quad$ Because of sample size limitations, it was not feasible to conduct separate analyses for African-Americans, Hispanics, and the foreign-born. 
The 1995 NSFG includes all Baptists in one category. In his research on the classification of Protestants into fundamentalist, moderate, and liberal, Smith (1987) distinguishes between seven different Baptist denominations, classifying six of them as fundamentalist and one as moderate. This limitation of the data implies that the respondents classified in the present paper as conservative Protestants include a small number of “moderate” religious groups.

$9 \quad$ While parents are likely to have considerable influence on their offspring's religious participation in early adolescence, important divergences often occur as children go through the highschool years. Whether or not such differences develop has been found to be a major factor in parents’ willingness to provide financial support for investments in schooling (Sherkat and Darnell 1999). 10 Although the 1995 NSFG also includes information on participation in religious services at the time of the survey, this variable was not used because it is more likely to be affected by problems of endogeneity: individuals with high wages may choose to participate less in religious activities because of their high value of time.

11 If the respondent was raised by some other "mother figure," such as a step-mother or grandmother, the information for this individual was used; the same was done in the case of the father. If educational attainment was missing for the father or mother, the value for the other parent was used.

12 Respondents were asked about the form of compensation in their current employment (weekly, monthly, or yearly). This study used the best available estimate of the wage rate, namely, the amount earned over the relevant interval divided by the number of hours worked during the period.

13 The full sample was used to estimate a probit labor force participation equation to correct for selectivity biases. The probit equation includes all of the determinants of wages plus variables for the 
number of children in the household, the presence of a child under age 6, marital status, and the husband's earnings if married (these results are available from the author). The inverse of Mill's ratio is shown as "Lambda" in Tables 5 and 6.

14 In a semilogarithmic regression, the percentage effect associated with c, the coefficient on a dummy variable, is $100(\exp (c)-1)$. See Halvorsen and Palmquist (1980).

15 Note that the wage regressions of Table 5, columns 2 and 4, include the inverse of Mill's ratio, which is a function in part of the non-market characteristics of the respondents. Additional analyses were conducted in which marital status, the presence of a child under age 6 , and the number of children, were entered directly in the wage regressions. None of the results described in the text changed appreciably in this alternative specification. 


\section{REFERENCES}

Albrecht, Stan L. and Tim B. Heaton. 1984. "Secularization, Higher Education, and Religiosity.” Review of Religious Research 26(1): 43-58.

Ayal, Eliezer B. and Barry R. Chiswick. 1983. “The Economics of the Diaspora Revisited.” Economic Development and Cultural Change 31(4): 861-875.

Bearman, Peter S. and Hannah Bruckner. 2001. "Promising the Future: Virginity Pledges and First Intercourse.” American Journal of Sociology 106(4): 859-912.

Becker, Gary S. 1967. Human Capital and the Personal Distribution of Income, Woytinsky Lecture No. 1. Ann Arbor, Michigan: University of Michigan Press.

Becker, Gary S. 1985. "Human Capital, Effort, and the Sexual Division of Labor.” Journal of Labor Economics 3 (1): S33-S58.

Becker, Gary S. and Barry R. Chiswick. 1966. "Education and the Distribution of Earnings.” American Economic Review 56 (May): 358-369.

Brenner, R. and Kiefer, N. 1981. "The Economics of Diaspora: Discrimination and Occupational Structure.” Economic Development and Cultural Change 517-533.

Brinkerhoff and MacKie. 1988. "Religious Sources of Gender Traditionalism.” Pp. 232-257 in D. Thomas (ed.) The Religion and Family Connection. Religious Studies Center, Brigham Young University, Salt Lake City.

Chiswick, Barry R. 1983. "The Earnings and Human Capital of American Jews," Journal of Human Resources 8: 313-336. 
- - - 1986. "Labor Supply and Investments in Child Quality: A Study of Jewish and NonJewish Women.” Review of Economics and Statistics 68(4): 700-703.

1988. "Differences in Education and Earnings Across Racial and Ethnic Groups:

Tastes, Discrimination, and Investments in Child Quality.” Quarterly Journal of Economics 103 (3): 571-597.

- - - - 1992. “The Postwar Economy of American Jews.” Studies in Contemporary Jewry 8: 85-101.

- - - - 1993. “The Skills and Economic Status of American Jewry: Trends Over the last HalfCentury.” Journal of Labor Economics 11(1): 229-242.

Darnell, Alfred and Darrel E. Sherkat. 1997. “The Impact of Protestant Fundamentalism on Educational Attainment.” American Sociological Review 62(April): 306-315.

Della Pergolla, Sergio. 1980. "Patterns of American Jewish Fertility”. Demography 17(3): 261-273.

Donahue, Michael J. and Peter L. Benson. 1995. "Religion and the Well-Being of Adolescents.” Journal of Social Issues 51(2): 145-160.

Ellison, Christopher G. and John P. Bartkowski. 2002. “Conservative Protestantism and the Division of Household Labor Among Married Couples.” Journal of Family Issues 23(8): 950-985.

Ellison, Christopher G., John P. Bartkowski, and Michelle L. Segal. 1996. “Conservative Protestantism and Support for Corporal Punishment.” Social Forces 74: 1003-29. 
Freeman, Richard B. 1986. "Who Escapes? The Relation of Churchgoing and Other Background Factors to the Socioeconomic Performance of Black Male Youths from Inner-City Tracts.” Pp. 353-376 in Richard B. Freeman and Harry J. Holzer (eds.) The Black Youth Employment Crisis. Chicago and London: The University of Chicago Press.

Glass, Jennifer. 1999. “Growing Up Fundamentalist: Effects on Women’s Early Life Course Transitions and Adult Attainment.” Presented at the annual meetings of the Population Association of America.

Glenn, Norval D. 1987. “The trend in 'No Religion’ Respondents to U.S. National Surveys, Late 1950s to Early 1980s.” The Public Opinion Quarterly 51(3): 293-314.

Halvorsen, Robert and Raymond Palmquist. 1980. “The Interpretation of Dummy Variables in Semilogarithmic Equations.” The American Economic Review 70(3): 474-475.

Harker, Kathryn. 2001. “Immigrant Generation, Assimilation, and Adolescent Psychological Well-Being.” Social Forces 79(3): 969-1004.

Hummer, Robert A., Y.C. Padilla, S. Echevarria, and E. Kim. 2002. “ Does Parental Religious Involvement Affect the Birth Outcomes and Health Status of Young children?” Presented at the annual meetings of the Population Association of America, Atlanta, May 9-11.

Jones, E. and C.F. Westoff. 1979. “The ‘End’ of Catholic Fertility.” Demography 16(2): 209218.

Kelly, Janice E., William D. Mosher, Allen P. Duffer and Susan H. Kinsey. 1997. Plan and operation of the 1995 National Survey of Family Growth. Vital and Health Statistics, Series $I$. 
Keister, Lisa A. 2003. "Religion and Wealth : The Role of Religious Affiliation and Participation in Early Adult Asset Accumulation.” Social Forces 82(1): 175-207.

Keysar, Ariela A. and Barry A. Kosmin. 1995. “The Impact of Religious Identification on Differences in Educational Attainment Among American Women in 1990.” Journal for the Scientific Study of Religion 34(1): 49-62.

Lehrer, Evelyn L. 1995. “The Effects of Religion on the Labor Supply of Married Women.” Social Science Research 24: 281-301.

- - - - 1996. “Religion as a Determinant of Marital Fertility.” Journal of Population Economics 9: 173-196.

1999. "Religion as a Determinant of Educational Attainment: An Economic

Perspective.” Social Science Research 28: 358-379.

- - - - 2004a. “The Role of Religion in Union Formation: An Economic Perspective.” Population Research and Policy Review 23: 161-185.

- - - - 2004b. "Religiosity as a Determinant of Educational Attainment: The Case of Conservative Protestant Women in the United States.” Review of Economics of the Household. 2(2): 203-219.

- - - - 2005. "Religious Affiliation and Participation as Determinants of High-School Completion.” Unpublished manuscript.

Lehrer, Evelyn and Carmel Chiswick. 1993. "Religion as a Determinant of Marital Stability.” Demography 30(3): 385-404.

Levin, Jeffrey S. 1994. "Religion and Health: Is There an Association, Is it Valid, and Is It Causal?” Social Science and Medicine 38(11): 1475-1482. 
Marchena, Elaine and Linda J. Waite. 2001. "Marriage and Childbearing Attitudes in Late Adolescence: Gender, Race and Ethnic Differences.” Revised version of paper presented at the meetings of the Population Association of America, March 2000, Los Angeles.

Muller, Chandra and Christopher G. Ellison. 2001. "Religious Involvement, Social Capital, and Adolescents’ Academic Progress: Evidence from the National Education Longitudinal Study of 1988.” Sociological Focus 34(2): 155-183.

Regnerus, Mark D. 2000. “Shaping Schooling Success: Religious Socialization and Educational Outcomes in Metropolitan Public Schools.” Journal for the Scientific Study of Religion 39: 363-370.

Regnerus, Mark. 2003. "Religion and Positive Adolescent Outcomes: A Review of Research and Theory.” Review of Religious Research 44(4): 394-413.

Sander, William. 1995. The Catholic Family: Marriage, Children, and Human Capital. Boulder: Westview Press.

Sherkat, Darnell E. 2000. “That they be Keepers of the Home: The Effect of Conservative Religion on Early and Late Transition into Housewifery.” Review of Religious Research 41(3): 344-358.

Sherkat, Darnell E. and Alfred Darnell . 1999. “The Effects of Parents’ Fundamentalism on Children’s Educational Attainment: Examining Differences by Gender and Children’s Fundamentalism.” Journal for the Scientific Study of Religion 38(1): 23-35.

Smith, Christian. 2003. “Theorizing Religious Effects Among American Adolescents.” Journal for the Scientific Study of Religion 42(1): 17-30. 
Smith, Tom W. 1987. “Classifying Protestant Denominations.” General Social Survey Methodological Report No. 43.

Stark, Rodney and William S. Bainbridge. 1985. The Future of Religion: Secularization, Revival, and Cult Formation. Berkeley: University of California Press.

Waite, Linda and Evelyn Lehrer. 2003. “The Benefits from Marriage and Religion in the United States: A Comparative Analysis.” Population and Development Review 29(2): 255-275.

Wilcox, W. Bradford. 1998. “Conservative Protestant Childrearing: Authoritarian or Authoritative?” American Sociological Review 63(6): 796-809. 
Table 1. Definitions and Means of Childhood Religious Affiliation and Participation

\begin{tabular}{|c|c|c|}
\hline & Definition & Mean $^{\mathrm{a}}$ \\
\hline Religious Affiliation & $\begin{array}{l}=1 \text { if respondent was raised in the affiliation } \\
\text { shown }\end{array}$ & \\
\hline (Mainline Protestant) & & $(0.30)$ \\
\hline Conservative Protestant & & 0.23 \\
\hline Catholic & & 0.35 \\
\hline Jewish & & 0.02 \\
\hline Mormon & & 0.03 \\
\hline No Religion & & 0.06 \\
\hline High Religiosity & $\begin{array}{l}=1 \text { if respondent attended religious services } \\
1-3 \text { times per month or more frequently at } \\
\text { age } 14\end{array}$ & 0.75 \\
\hline $\begin{array}{l}\text { Religious Affiliation and } \\
\text { Religiosity } \\
\text { Mainline Protestant-low } \\
\text { (Mainline Protestant-high) } \\
\text { Conservative Protestant-low } \\
\text { Conservative Protestant-high } \\
\text { Catholic- high } \\
\text { Catholic- low }\end{array}$ & $\begin{array}{l}=1 \text { if respondent had the religious affiliation } \\
\text { and participation indicated }\end{array}$ & $\begin{array}{l}0.07 \\
(0.23) \\
0.05 \\
0.18 \\
0.30 \\
0.05\end{array}$ \\
\hline $\mathrm{n}=4,181$ & & \\
\hline
\end{tabular}


Table 2. Definitions and Means of Control Variables

$$
\text { Definition }
$$

Mean $^{a}$

\begin{tabular}{|c|c|c|}
\hline \multicolumn{3}{|c|}{ Controls in Education Regressions } \\
\hline Parental education & \multicolumn{2}{|l|}{$\begin{array}{l}=1 \text { if the average years of schooling completed by the } \\
\text { respondent's ( } \mathrm{R} \text { ) father (or father figure) and mother (or } \\
\text { mother figure) is in category indicated }\end{array}$} \\
\hline$<12$ & & 0.37 \\
\hline$(12)$ & (benchmark) & $(0.26)$ \\
\hline $13-15$ & & 0.25 \\
\hline$\geq 16$ & & 0.12 \\
\hline Nonintact family & $\begin{array}{l}=1 \text { if } \mathrm{R} \text { did not live with both biological or adoptive parents at } \\
\text { age } 16 \text { for the reason indicated: }\end{array}$ & \\
\hline Death & death of one of the parents & 0.07 \\
\hline Separation or divorce & parents' separation or divorce & 0.19 \\
\hline $\begin{array}{l}\text { Never married } \\
\text { (Intact family) }\end{array}$ & $\begin{array}{l}\mathrm{R} \text { never lived with both natural (or adoptive) parents } \\
\text { (benchmark) }\end{array}$ & $\begin{array}{l}0.04 \\
(0.70)\end{array}$ \\
\hline $\begin{array}{l}\text { Mother } 18 \text { years old or } \\
\text { younger at first birth }\end{array}$ & $=1$ if R's mother (figure) had her first child at age 18 or earlier & 0.10 \\
\hline Number of siblings & number of children born to R's mother (or mother figure) & 3.95 \\
\hline Region at birth & $=1$ if $\mathrm{R}$ was born in the region indicated & \\
\hline Northeast & & 0.24 \\
\hline Midwest & & 0.33 \\
\hline West & & 0.17 \\
\hline (South) & & $(0.26)$ \\
\hline \multicolumn{3}{|c|}{ Controls in Wage Regressions } \\
\hline Years of schooling & number of years of regular schooling completed by $\mathrm{R}$ & 13.37 \\
\hline $\begin{array}{l}\text { Years of full-time } \\
\text { experience }\end{array}$ & number of years of full-time work in the labor market & 11.69 \\
\hline $\begin{array}{l}\text { Years of part-time } \\
\text { experience }\end{array}$ & number of years of part-time work in the labor market & 2.71 \\
\hline Region of residence & $=1$ if $\mathrm{R}$ currently lives in the region indicated & \\
\hline Northeast & & 0.20 \\
\hline Midwest & & 0.30 \\
\hline West & & 0.20 \\
\hline (South) & & $(0.30)$ \\
\hline Rural Area & $=1$ if $\mathrm{R}$ currently lives in a rural area & 0.18 \\
\hline \multicolumn{3}{|c|}{$\mathrm{n}=4,181$ for education regressions; $\mathrm{n}=2,844$ for wage regressions } \\
\hline
\end{tabular}


Table 3. The Role of Religious Affiliation on Educational Attainment

Dependent Variable: Years of Schooling Completed

(t-values in parentheses)

\author{
Zero-order effects $\quad$ Controlling for background variables
}

\begin{tabular}{|c|c|c|c|}
\hline \multicolumn{4}{|l|}{ Control Variables } \\
\hline \multicolumn{4}{|l|}{ Parental education } \\
\hline \multicolumn{2}{|l|}{ Under 12} & & $-0.663(-8.0)^{* *}$ \\
\hline \multicolumn{2}{|l|}{$13-15$} & & $0.942(10.6)^{* *}$ \\
\hline \multicolumn{2}{|l|}{$\geq 16$} & & $2.171(19.2)^{* *}$ \\
\hline \multicolumn{4}{|l|}{ Nonintact family } \\
\hline \multicolumn{2}{|l|}{ Death } & $-0.391(-2.9)^{* *}$ & $-0.302(-2.5)^{* *}$ \\
\hline \multicolumn{2}{|l|}{ Separation or divorce } & $-0.751(-8.4)^{* *}$ & $-0.669(-8.1)^{* *}$ \\
\hline \multicolumn{2}{|l|}{ Never married } & $-1.040(-5.6)^{* *}$ & $-0.871(-5.1)^{* *}$ \\
\hline \multicolumn{2}{|l|}{$\begin{array}{l}\text { Mother } 18 \text { years old or } \\
\text { younger at first birth }\end{array}$} & $-1.082(-9.1)^{* *}$ & $-0.567(-5.1)^{* *}$ \\
\hline \multicolumn{2}{|l|}{ Number of siblings } & $-0.126(-7.5)^{* *}$ & $-0.091(-5.9)^{* *}$ \\
\hline \multicolumn{4}{|l|}{ Region at birth } \\
\hline \multicolumn{2}{|l|}{ Northeast } & $-0.057(-0.5)$ & $0.020(0.2)$ \\
\hline \multicolumn{2}{|l|}{ West } & $0.180(1.6)^{*}$ & $-0.076(-0.7)$ \\
\hline \multicolumn{2}{|l|}{ Midwest } & $-0.123(-1.3)$ & $-0.052(-0.6)$ \\
\hline \multicolumn{4}{|l|}{ Religion Variables } \\
\hline Mainline Protestant & - - & - - & - - \\
\hline Conservative Protestant & $-1.168(-11.9)^{* *}$ & $-0.911(-9.0)^{* *}$ & $-0.509(-5.4)^{* *}$ \\
\hline Catholic & $0.067(0.8)$ & $0.147(1.7)^{*}$ & $0.193(2.4)^{* *}$ \\
\hline Jewish & $2.280(8.3)^{* *}$ & $2.056(7.7)^{* *}$ & $1.540(6.3)^{* *}$ \\
\hline Mormon & $-0.611(-3.0)^{* *}$ & $-0.511(-2.5)^{* *}$ & $-0.330(-1.8)^{*}$ \\
\hline No religion & $-0.583(-3.6)^{* *}$ & $-0.319(-2.0) * *$ & $-0.199(-1.4)$ \\
\hline Constant & $13.547(209.6)^{* *}$ & $14.288(130.2)^{* *}$ & $13.717(119.75)^{* *}$ \\
\hline Adjusted $\mathrm{R}^{2}$ & 0065 & 0.126 & 0.263 \\
\hline
\end{tabular}


Table 4. The Role of Religiosity on Educational Attainment

Dependent Variable: Years of Schooling Completed (t-values in parentheses)

Zero-order effects Controlling for background variables

\begin{tabular}{|c|c|c|c|}
\hline \multicolumn{4}{|l|}{ Control Variables } \\
\hline \multicolumn{4}{|l|}{ Parental education } \\
\hline \multicolumn{2}{|l|}{ Under 12} & & $-0.656(-8.0)^{* *}$ \\
\hline \multicolumn{2}{|l|}{$13-15$} & & $0.930(10.5)^{* *}$ \\
\hline \multirow{2}{*}{\multicolumn{2}{|c|}{$\begin{array}{l}\geq 16 \\
\text { Nonintact family }\end{array}$}} & & $2.148(19.1)^{* *}$ \\
\hline & & & \\
\hline \multicolumn{2}{|l|}{ Death } & $-0.372(-2.8)^{* *}$ & $-0.287(-2.4)^{* *}$ \\
\hline \multicolumn{2}{|l|}{ Separation or divorce } & $-0.636(-7.0)^{* *}$ & $-0.573(-6.9)^{* *}$ \\
\hline \multicolumn{2}{|l|}{ Never married } & $-0.983(-5.4)^{* *}$ & $-0.826(-4.9) * *$ \\
\hline \multicolumn{2}{|l|}{$\begin{array}{l}\text { Mother } 18 \text { years old or } \\
\text { younger at first birth }\end{array}$} & $-1.043(-8.9)^{* *}$ & $-0.543(-4.9)^{* *}$ \\
\hline \multicolumn{2}{|l|}{ Number of siblings } & $-0.133(-8.0)^{* *}$ & $-0.098(-6.3)^{* *}$ \\
\hline \multicolumn{4}{|l|}{ Region at birth } \\
\hline \multicolumn{2}{|l|}{ Northeast } & $-0.029(-0.3)$ & $0.044(0.5)$ \\
\hline \multicolumn{2}{|l|}{ West } & $0.227(2.0)$ & $-0.033(-0.3)$ \\
\hline \multicolumn{2}{|l|}{ Midwest } & $-0.108(-1.1)$ & $-0.037(-0.4)$ \\
\hline \multicolumn{4}{|l|}{ Religious Affiliation and } \\
\hline \multicolumn{4}{|l|}{ Religiosity Variables } \\
\hline Mainline Protestant-high & - - & - - & - - \\
\hline Mainline Protestant- low & $-0.432(-2.9)^{* *}$ & $-0.318(-2.2) * *$ & $-0.280(-2.1)^{* *}$ \\
\hline Conservative Protestant-high & $-1.057(-9.6) * *$ & $-0.797(-7.1)^{* *}$ & $-0.403(-3.8) * *$ \\
\hline Conservative Protestant-low & $-2.049(-11.8)^{* *}$ & $-1.682(-9.8)^{* *}$ & $-1.229(-7.7)^{* *}$ \\
\hline Catholic_- high & $0.120(1.2)$ & $0.210(2.2)^{* *}$ & $0.231(2.6)^{* *}$ \\
\hline Catholic_- low & $-0.880(-5.3)^{* *}$ & $-0.656(-4.0)^{* *}$ & $-0.425(-2.8) * *$ \\
\hline Jewish & $2.176(8.0)^{* *}$ & $1.978(7.4)^{* *}$ & $1.478(6.0)^{* *}$ \\
\hline Mormon & $-0.715(-3.5)^{* *}$ & $-0.600(-2.9)^{* *}$ & $-0.409(-2.2)^{* *}$ \\
\hline No religion & $-0.688(-4.2)^{* *}$ & $-0.423(-2.6)^{* *}$ & $-0.291(-2.0)^{* *}$ \\
\hline Constant & $13.651(185.6)^{* *}$ & $14.346(126.0)^{* *}$ & $13.773(116.8)^{* *}$ \\
\hline Adjusted $\mathrm{R}^{2}$ & 0.082 & 0.138 & 0.274 \\
\hline
\end{tabular}

$\mathrm{n}=4,181$

${ }^{* *} \mathrm{p}<0.05 ; * \mathrm{p}<0.10$

Note: The t-values for the religion variables reflect comparisons against the omitted category: highreligiosity mainline Protestants. Pairwise comparisons between low and high religiosity conservative Protestants, and between low and high religiosity Catholics reveal differences that are significant at the $5 \%$ level in all models. 
Table 5: The Role of Religious Affiliation on Wages

Dependent Variable: In Wage

(t-values in parentheses)

\begin{tabular}{|c|c|c|c|c|}
\hline & \multicolumn{2}{|c|}{ Childhood Affiliation } & \multicolumn{2}{|c|}{ Adult Affiliation } \\
\hline & Zero-order effects & $\begin{array}{l}\text { Controlling for } \\
\text { other } \\
\text { determinants of } \\
\text { wages }\end{array}$ & Zero-order effects & $\begin{array}{l}\text { Controlling for } \\
\text { other } \\
\text { determinants of } \\
\text { wages }\end{array}$ \\
\hline \multicolumn{5}{|l|}{ Control Variables } \\
\hline Years of schooling & & $0.104(20.0)^{* *}$ & & $0.104(19.6)^{* *}$ \\
\hline $\begin{array}{l}\text { Years of full-time } \\
\text { experience }\end{array}$ & & $0.033(11.8)^{* *}$ & & $0.034(11.8)^{* *}$ \\
\hline $\begin{array}{l}\text { Years of part-time } \\
\text { experience }\end{array}$ & & $0.017(4.8)^{* *}$ & & $0.012(4.9)^{* *}$ \\
\hline \multicolumn{5}{|l|}{ Region of residence } \\
\hline Northeast & & $0.080(2.2)^{* *}$ & & $0.076(2.2)^{* *}$ \\
\hline Midwest & & $-0.040(-1.3)$ & & $-0.045(-1.4)$ \\
\hline West & & $0.080(2.3)^{* *}$ & & $0.081(2.3)^{* *}$ \\
\hline Rural area & & $-0.130(-4.3)^{* *}$ & & $-0.104(-3.4)^{* *}$ \\
\hline \multicolumn{5}{|l|}{ Religion Variables } \\
\hline Mainline Protestant & -- & -- & -- & -- \\
\hline Conservative Protestant & $-0.153(-4.5)^{* *}$ & $-0.028(-0.8)$ & $-0.206(-5.8) * *$ & $-0.071(-2.1)^{* *}$ \\
\hline Catholic & $0.065(2.2)^{* *}$ & $0.010(0.4)$ & $0.038(1.2)$ & $0.002(0.1)$ \\
\hline Jewish & $0.580(6.1)^{* *}$ & $0.327(3.7)^{* *}$ & $0.593(6.1)^{* *}$ & $0.334(3.7)^{* *}$ \\
\hline Mormon & $-0.301(-4.1)^{* *}$ & $-0.249(-3.7)^{* *}$ & $-0.228(-2.9)^{* *}$ & $-0.190(-2.7)^{* *}$ \\
\hline No religion & $-0.074(-1.3)$ & $0.001(0.01)$ & $-0.107(-2.5)^{* *}$ & $-0.068(-1.8) *$ \\
\hline Constant & 2.367 (106.7) & $0.448(4.2)^{* *}$ & $2.391(105.5)^{* *}$ & $0.465(4.3)^{* *}$ \\
\hline Lambda & & $0.196(3.0)^{* *}$ & & $0.212(3.2)^{* *}$ \\
\hline Adjusted $\mathrm{R}^{2}$ & 0.033 & 0.232 & 0.036 & 0.231 \\
\hline $\mathrm{n}$ & 2,844 & 2,844 & 2,778 & 2,778 \\
\hline
\end{tabular}


Table 6: The Role of Religiosity on Wages

Dependent Variable: In Wage

(t-values in parentheses)

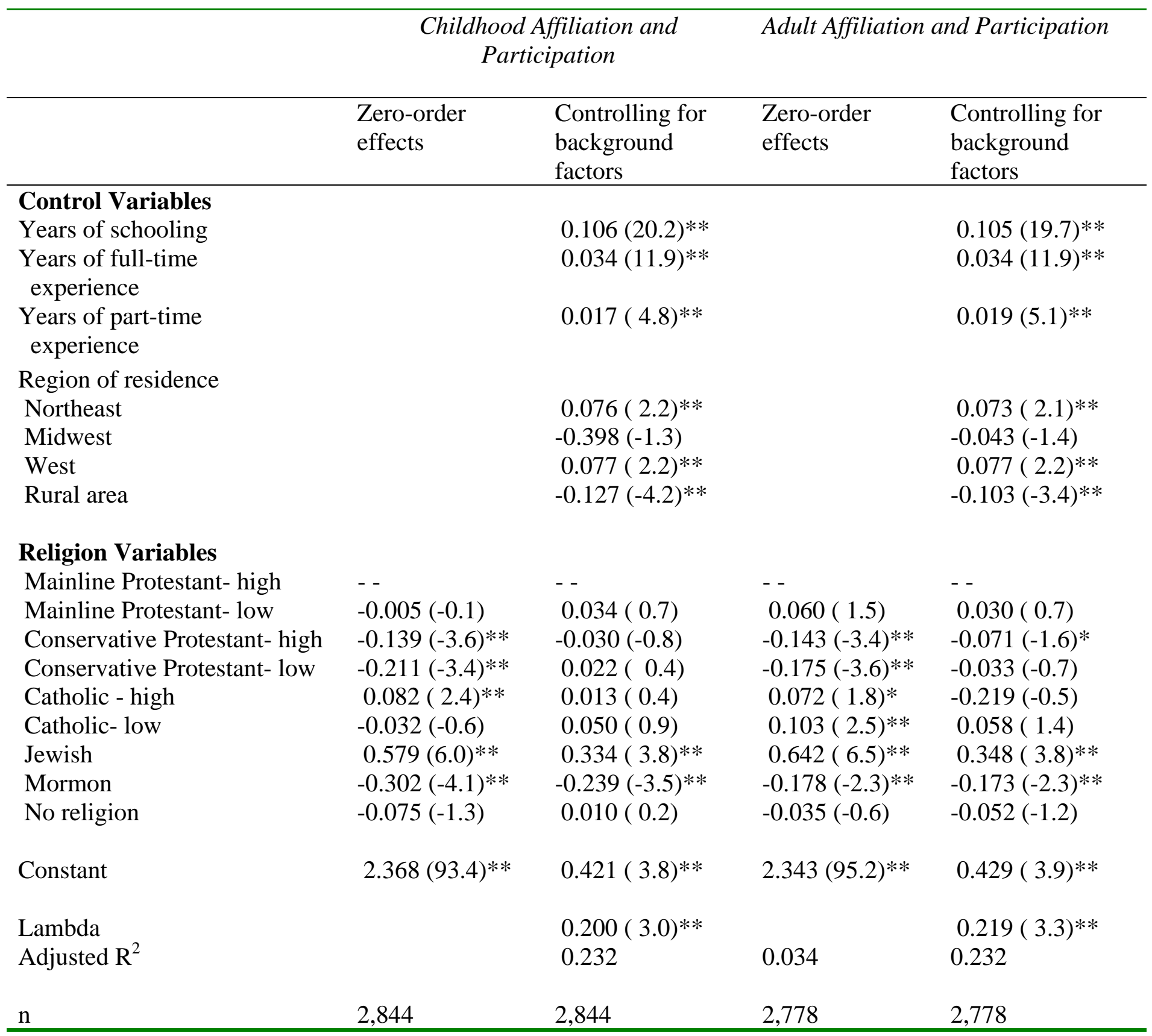

Note. The t-values for the religion variables reflect comparisons against the omitted category: highreligiosity mainline Protestants. Pairwise comparisons between the low and high religiosity categories for each group reveal differences that are insignificant in all cases, with one exception: the difference between high and low religiosity Catholics in the first model. 